\title{
Digital Technology Entrepreneurship: A Definition and Research Agenda
}

\section{Ferran Giones and Alexander Brem}

\author{
" Entrepreneurship is the key to emerging technologies." \\ James H. Clark \\ Entrepreneur and computer scientist
}

\begin{abstract}
Technology entrepreneurship is an established concept in academia. However, recent developments in the context of digital entrepreneurship call for revision and advancement. The multiple possible combinations of technology and entrepreneurship have resulted in a diversity of phenomena with significantly different characteristics and socio-economic impact. This article is focused on the identification and description of technology entrepreneurship in times of digitization. Based on current examples, we identify and describe characterizations of technology entrepreneurship, digital technology entrepreneurship, and digital entrepreneurship. With this new delineation of terms, we would like to foster discussion between researchers, entrepreneurs, and policy makers on the impact of digitization on entrepreneurship, and set a future research agenda.
\end{abstract}

\section{Introduction}

Do we need another definition in entrepreneurship research? We argue that at least technology entrepreneurship deserves a revision. Indeed, Mosey, Guerrero, and Greenman (2017) have stated that, after two decades of interest and research contributions in the field, we all can now take stock of what has been achieved, what needs to be revisited, and what is still missing. We have reached a consolidation stage in technology entrepreneurship research.

A seminal contribution to the definition of technology entrepreneurship as a field was made by Tony Bailetti. His definition highlights that technology entrepreneurship is "an investment in a project that assembles and deploys specialized individuals and heterogeneous assets that are intricately related to advances in scientific and technological knowledge for the purpose of creating and capturing value for a firm" (Bailetti, 2012). Around the time when Bailetti's article was published, the largest ever initial public offering (IPO) from a technology company took place: Facebook raised over $\$ 16$ billion USD upon becoming listed in the stock market (Rusli \& Eavis, 2012). In subsequent five years after Facebook became a public company, we have witnessed a mobile and social media revolution (Hanna et al., 2011). This revolution has not only changed how organizations connect with customers, but it has also transformed the meaning of technology entrepreneurship.
To make sense of how much digitization has changed technology entrepreneurship, we propose to examine the topic from three different angles: the underlying technological opportunity, the entrepreneurship process, and the resource acquisition. Prior research has highlighted the entrepreneur-opportunity nexus, suggesting that the type and nature of a technology opportunity can be a determining factor in the activation of the entrepreneurial process (Davidsson, 2015; Gruber et al., 2012). Similarly, the entrepreneurial activities and their sequence (Brush et al., 2008; Lichtenstein, 2015) or the acquisition and timing of resources affect survival and the likelihood of growth (Bhawe et al., 2016; Klyver \& Schenkel, 2013). These complementary perspectives allow us to identify and describe entrepreneurship cases where we can observe how digitization has permeated technology entrepreneurship.

We follow the approach of MacInnis (2011) to identify and describe characterizations of the concept, and then determine and differentiate the theoretical and practical implications. First, we describe the different types of technology entrepreneurship and their characteristics. Based on that, we propose and discuss a conceptual differentiation. Finally, we identify the implications for researchers, entrepreneurs, or other actors active in the promotion of technology entrepreneurship. 


\section{Digital Technology Entrepreneurship: A Definition and Research Agenda}

\section{Ferran Giones and Alexander Brem}

\section{New Forms of Technology Entrepreneurship}

The absence of a detailed characterization of technology entrepreneurship makes it difficult to determine whether we are still inside the original concept boundaries. In their recent systematic literature review, Ferreira and colleagues (2016) opt for a broad conceptualization of technology entrepreneurship, suggesting that it is a combination of entrepreneurship and technology-based innovation. Similarly, Beckman and colleagues (2012) wrote in their special issue on technology entrepreneurship that it is a type of entrepreneurship that aims to exploit opportunities related to advances in science and engineering. Both conceptualizations are broad and are rather consistent with Bailetti's (2012) approach.

An unexpected challenge to this conceptualization has evolved through the meaning of "technology". Although most of technology entrepreneurship research started by studying new entrants in high-tech industries (Gans \& Stern, 2003), much attention has been given to the technology commercialization efforts of new firms such as academic spin-offs (Fryges \& Wright, 2014; Mosey et al., 2017; Wright et al., 2007). As a result, the phenomenon under study was usually characterized as a technology-push situation (Brem \& Voigt, 2009), where the entrepreneur had the mission to find an application and create a market for a new and complex technology (Giones et al., 2013). But how much does this perspective fit with entrepreneurial activity using digital technologies? As recently discussed by Nambisan (2016), the digitization of the "technology" not only changes its properties but also impacts the overall technology entrepreneurship process. Apparently, this has also major impacts on entrepreneurial processes in general.

To explore the potential differences between alternative characterizations, we first present potentially different, but related forms, of technology entrepreneurship, as shown in Table 1.

Instead of looking for an exhaustive characterization, Table 1 offers a first impression of the diversity of forms that technology entrepreneurship can take. Even in the extreme case of pure digital entrepreneurship, it can be argued that it rarely fits within a technology-push perspective, being instead much closer to concepts such as recombinant innovation or demand-driven approaches to technological innovation in the understanding of market-pull (Brem \& Voigt, 2009; Priem et al., 2011). From a research perspective, digital entrepreneurship is much closer to the information systems' concepts of artefacts, platforms, and information infrastructure

Table 1. Alternative forms of technology and digital entrepreneurship

\begin{tabular}{|c|c|c|c|}
\hline Typology & $\begin{array}{l}\text { Technology Behind the } \\
\text { Opportunity }\end{array}$ & Key Activities in the Process & $\begin{array}{l}\text { Access to Resources and } \\
\text { Funding }\end{array}$ \\
\hline $\begin{array}{l}\text { Technology } \\
\text { Entrepreneurship }\end{array}$ & $\begin{array}{l}\text { New products based on } \\
\text { breakthroughs in research; } \\
\text { science-based advances through } \\
\text { specific knowledgein an } \\
\text { academic field } \\
\text { Example: Graphene }\end{array}$ & $\begin{array}{l}\text { Technology proof of concept: } \\
\text { first customer validation; activate } \\
\text { a global but niche market } \\
\text { (Clarysse et al., 2011) }\end{array}$ & $\begin{array}{l}\text { Public research grants and other } \\
\text { soft money sources } \\
\text { Venture capital attracted by } \\
\text { promising intellectual property } \\
\text { (Audretsch et al., 2012; Giones \& } \\
\text { Miralles, 2015) }\end{array}$ \\
\hline $\begin{array}{l}\text { Digital } \\
\text { Technology } \\
\text { Entrepreneurship }\end{array}$ & $\begin{array}{l}\text { New products based on ICT } \\
\text { technologies only; making smart } \\
\text { devices using the possibilities of } \\
\text { Internet of Things } \\
\text { Example: Smartphone }\end{array}$ & $\begin{array}{l}\text { Use of existing technologies: } \\
\text { market validation, traction, and } \\
\text { growth, scalability }\end{array}$ & $\begin{array}{l}\text { Business angels; seed and } \\
\text { venture capital; stock market } \\
\text { Crowdfunding: reward and } \\
\text { equity (Gedda et al., 2016) }\end{array}$ \\
\hline $\begin{array}{l}\text { Digital } \\
\text { Entrepreneurship }\end{array}$ & $\begin{array}{l}\text { New products and services based } \\
\text { on the Internet. Services running } \\
\text { only in the cloud; using big data } \\
\text { or artificial intelligence. } \\
\text { Example: Snapchat }\end{array}$ & $\begin{array}{l}\text { Technology as an input factor: } \\
\text { high growth ambitions (Wallin et } \\
\text { al., 2016); stay ahead of } \\
\text { competitors; be the dominant } \\
\text { player in the category }\end{array}$ & $\begin{array}{l}\text { Business angels; seed and } \\
\text { venture capital; stock market } \\
\text { Equity crowdfunding (Tomczak \& } \\
\text { Brem, 2013) }\end{array}$ \\
\hline
\end{tabular}




\section{Digital Technology Entrepreneurship: A Definition and Research Agenda}

\section{Ferran Giones and Alexander Brem}

(Nambisan, 2016). Digital entrepreneurs often do not really care about the specific technology behind their business idea, they simply focus on the service that is based on it. Hence, technology here is an input factor only. Digital technology entrepreneurship refers to the technology: its products are technological.

To further clarify this potential divide, in Table 2 we present some examples of entrepreneurial firms that could help reveal the existing differences across the types of technology entrepreneurship.
As the examples in Table 2 illustrate, the type of technology that triggers the entrepreneurship story behind the cases is different. It is not only a discussion about whether we are talking about software or hardware firms, or whether these entrepreneurs aim to only offer services or combine products and services. The typologies we propose aim to connect the traditional sciencebased technology entrepreneurship coming from university intellectual property (Hartmann, 2014) to the new and rapidly evolving Internet-based digital startups (Drori et al., 2009).

Table 2. Examples of different types of technology and digital entrepreneurship

\begin{tabular}{ll}
\hline Typology & Example \\
\hline Technology & Fractus \\
Entrepreneurship & (www.fractus.com)
\end{tabular}

Started as an academic spin-off, Fractus was a pioneer in the development of internal antennas for smartphones. They first attempted to commercialize their new antenna designs as a finished product, but then realized that it made more sense to just focus on $R \& D$, patenting, and licensing their technology to manufacturers and OEMs such as Nokia, Samsung, or Motorola.

Oryzon Genomics

Founded by bio-pharmaceutical researchers, Oryzon's first decade of operations was focused in (www.oryzon.com) offering genomics diagnostics. The company took-off in 2008 when it shifted its focus on developing proprietary drug candidates and licensing to large pharmaceutical companies such as Roche.

Rust Patrol The technology was invented by a chemistry professor, and it offered a potential alternative (www.rustpatrol.com) solution to address metal corrosion. A decade later, in 2014, two students joined the researcher to successfully start commercializing anti-corrosion products for industrial and consumer needs.

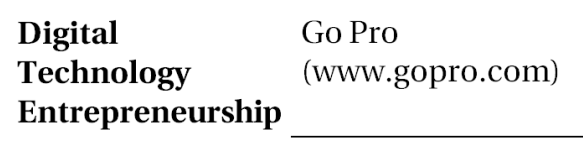

Fitbit

(www.fitbit.com)

Tesla

(www.tesla.com)

\begin{abstract}
Founded by a surfer frustrated with the limited options he had to take nice action shots, Go Pro became a manufacturer of action cameras and created a new category in the market. It is a good example of user entrepreneurship (Shah \& Tripsas, 2007).
\end{abstract}




\section{Digital Technology Entrepreneurship: A Definition and Research Agenda}

\section{Ferran Giones and Alexander Brem}

The typologies and examples in Tables 1 and 2 are provided to group together similar evolution paths and growth trajectories. This comes as a response to the diversity of technology origins and outcomes that make it unfeasible to extract homogeneous insights from them if treated as a sole category. We argue instead that it might be a much more fruitful avenue to explore how some of these organizations have benefited from lean startup approaches (Frederiksen \& Brem, 2017) or how they have activated a global niche for their products (Tanev, 2012).

Furthermore, each of these types of firms might respond to specific entrepreneurial motivations in their founders. Some might be driven by the idea to address a social problem, whereas others might be excited by the ambition to build a firm that makes an economic impact and becomes a respected institution. These motivations can reflect a combination of multiple entrepreneurial identities or a specific dominant identity (Fauchart \& Gruber, 2011). The social identity of the entrepreneur behind each of these firms has implications for the goals they set, as well as for the exit routes that they might be able to define (Dehlen et al., 2014). However, digital entrepreneurs expect to be able to sell their firms to a larger player, resulting in the effective transfer of their user base to a new firm. Pure technology or digital technology entrepreneurs carry with them technology assets that can either be the focus of interest of the acquirer or a costly asset that makes the acquisition price unattractive.

In the following section, we aim to suggest promising directions to further explore technology entrepreneurship considering the different shapes and forms that digital technologies have triggered.

\section{Implications for Digital Technology Entrepreneurship Theory and Practice}

The digital transformation of most of the input technologies that entrepreneurs use to propose their new innovative ventures has extended the types of technology entrepreneurs we can observe. Instead of proposing a clear-cut conceptualization between digital and technology entrepreneurship, we propose to describe the change in meaning of "technology" as a continuum between the extremes represented by the commercialization of the latest scientific breakthroughs (e.g., a new material like graphene) and the latest application for smartphones (e.g., a new food delivery app). Figure 1 shows the overlap between these concepts.
As a result, the concept of digital technology entrepreneurship necessarily combines elements of technology and digital entrepreneurship. Thus, we propose to enrich Bailetti's (2012) definition of technology entrepreneurship to include specific aspects related to this specific form of entrepreneurship: digital technology entrepreneurship is focused on the identification and exploitation of opportunities based on scientific or technological knowledge through the creation of digital artefacts. Digital technology entrepreneurs build firms based on technologies on the one hand, and on services on the other hand.

The extension of the definition implies that this profile of entrepreneurs do not only experience the challenges of engineering or scientific development, but also the complex dynamics of digital platforms and infrastructures (Nambisan, 2016). Digital technology entrepreneurs do not only rely on an innovation ecosystem as digital entrepreneurs do. They strategically combine technological product knowledge ("technology push") with consumer know-how ("market pull"). But why introduce these terms - are there not already enough definitions in the area of entrepreneurship, as mentioned earlier? From an academic perspective, researchers could use the different classifications of entrepreneurship to learn more about the personal motivations of entrepreneurs and their founding behaviours, financing preferences, etc. One may further argue that such labels might not be relevant to the entrepreneurs themselves. However, we believe that, when it comes to entrepreneurs aspiring to start a business, it might help them to make a conscious decision on what type of technology entrepreneur they want to be.

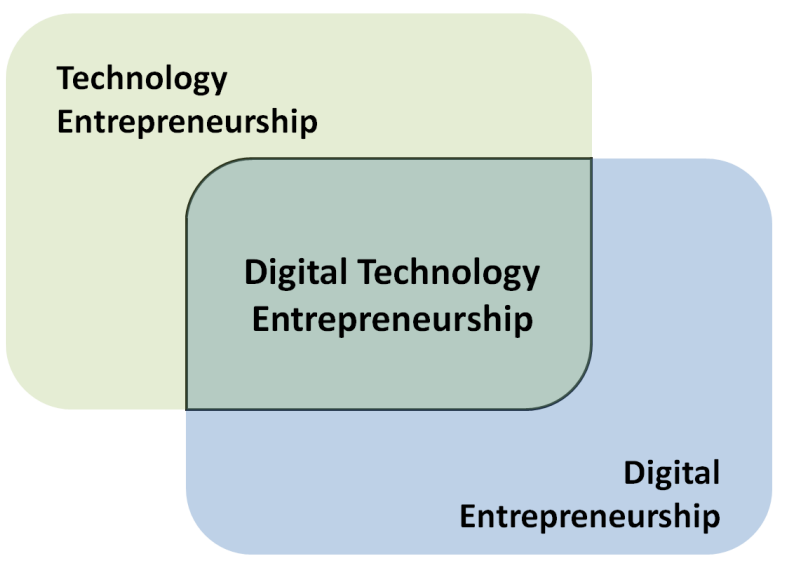

Figure 1. Conceptual representation of a new type of technology entrepreneurship: digital technology entrepreneurship 


\section{Digital Technology Entrepreneurship: A Definition and Research Agenda}

\section{Ferran Giones and Alexander Brem}

Indeed, the introduction of digital technologies as an input for entrepreneurship opens further opportunities for researchers, entrepreneurs, and policy makers. Below, we discuss the implications of our new characterizations of technology entrepreneurship, digital technology entrepreneurship, and digital entrepreneurship for each of these groups.

\section{Researchers}

In traditional forms of technology entrepreneurship, the key decision of the entrepreneur was to select whether to aim for licensing their technology or engage in the full commercialization of their product (Gans \& Stern, 2003). In contrast, digital technology entrepreneurs are embedded in an interconnected system when they aim to commercialize their solutions; it is a context where platforms and network effects matter (Kyprianou, 2016; Srinivasan et al., 2004) and standards or dominant designs (Brem et al., 2016) can define the boundaries and scalability of products. As a result, there are opportunities to update what we know about growth patterns in technology entrepreneurship (Hesse \& Sternberg, 2016) to include digital technology entrepreneurs. Related research questions include:

-What are the implications of building a new venture on a digital artefact? What is different in resource acquisition, team dynamics, or funding strategies?

-What are the implications of growth in digital technology entrepreneurship? How is it different from technology entrepreneurship or digital entrepreneurship? When does growth stop being a desirable outcome for entrepreneurs? How do valuation, user, and revenue growth translate into different entrepreneurship processes and perceptions of success?

Further research could also study the co-evolution between digital technology entrepreneurship and the digital platforms or infrastructure governance (Wareham et al., 2014), as well as the impact of regulation (Gurses \& Ozcan, 2015) to explore when this enables or constrains entrepreneurial activity. Related research questions include:

- How do platform dynamics impact entrepreneurial activity in emerging ecosystems? When does too much dynamism reduce the ecosystem attractiveness to new potential entrants? When does entrepreneurial activity generate new innovations, and when does it not?
-When do entrepreneurs engage in transforming the digital platforms where they operate? How does regulation by code and by law explain the different evolutionary paths in different markets?

- What strategies do entrepreneurs use to protect their positions in unstructured ecosystems? What is different in digital infrastructures? When do digital entrepreneurs use regulation to their advantage?

To explore this and related research questions, researchers might take advantage of methods and theoretical perspectives from information systems' research, where we have seen similar research fields' interconnections in the last years between innovation and information systems (Majchrzak \& Malhotra, 2013). Promising approaches include:

- Introducing heuristics theorizing to build design theories in entrepreneurship research (Gregory \& Muntermann, 2014).

- Bringing multilevel perspectives (Shepherd, 2010) that capture the complexity of digital technology entrepreneurship, or different angles such as real options to understand how stakeholders see and make decisions in technology entrepreneurship (Rasmussen \& Mathisen, 2016).

\section{Entrepreneurs}

The introduction of digital elements in the technology entrepreneurship process also reveals a bright side for entrepreneurs. For example, the digital aspects of the technology favour the adoption of born-global approaches (Kraus et al., 2017; Tanev, 2012). These firms can quickly scale up their products and aim for a global audience. Furthermore, the digitization of the production processes makes it possible to be both a lean and global company at the same time (Frederiksen \& Brem, 2017; Rasmussen \& Tanev, 2015), blurring the traditional boundaries of technology entrepreneurship. Activities in the entrepreneurship process, such as resource acquisition, are also changing; digital technologies offer the possibility to bring forth early working prototypes that can be used in reward crowdfunding campaigns, completely changing the technology innovation management process in the new firm (Giones \& Oo, 2017). With so many possible futures, the ability to design and innovate the business model makes a difference (Doganova \& Eyquem-Renault, 2009; Westerlund et al., 2014). 


\section{Digital Technology Entrepreneurship: A Definition and Research Agenda}

\section{Ferran Giones and Alexander Brem}

There is also a dark side to the digital potential of technology entrepreneurship. Fast growth and forward leaps often mean higher failure risks for the ambitious digital entrepreneurs stepping into emerging ecosystems, where the role of each of the players is still unclear and the technology base is still evolving. Westerlund, Leminen, and Rajahonka (2014) describe the example of new entrants in the Internet of Things (IoT) ecosystem, where the lack of structure and solid standards (Brem et al., 2016) in the ecosystem increase the complexity of entrepreneurs' decisions.

To sum up, the digital artefact at the core of the entrepreneurship process might require or call for additional information management capabilities in the entrepreneurial team, but it also opens new doors to accelerate learning and growth in the new venture.

\section{Policy makers}

The consequence of digitization goes beyond the dynamics of the entrepreneurship process. An example of how digital technology entrepreneurship is also activating new policy and support mechanisms is the successful I-Corps program (http://www.nsf.gov/i-corps) run by the National Science Foundation in the United States. The digital core of new technologies makes it possible to run accelerated approaches to market validation and early-stage growth.

As a result, the model of the university incubator for technology entrepreneurship (Amezcua et al., 2013; Gerlach \& Brem, 2015) no longer fits with the characteristics of digital technology entrepreneurship. Instead, we observe how an increasing number of research centres and universities are starting to partially or fully introduce entrepreneurship-supported models that follow the accelerator program design (Pauwels et al., 2016). The transition from incubation to acceleration models requires specific knowledge, dynamic markets, and an investor ecosystem; done in isolation, it is likely to end up in the black-box of failed policies (Brown \& Mason, 2014).

\section{Conclusion}

The unprecedented digital revolution has transformed the meaning and forms of entrepreneurship across the globe. The emerging field of technology entrepreneurship research has not been able to keep pace with the fast changes in the digitization of our society and economy. In this article, we aim to help entrepreneurs and researchers interested in further exploring the possibilities that new technologies and entrepreneurship generate. We propose a conceptualization and characterization of three different phenomena: technology entrepreneurship, digital technology entrepreneurship, and digital entrepreneurship. Each of them has a different origin and different emergence dynamics, and in most cases, they generate rather different trajectories for growth and technology evolution. The uniqueness and novelty of the phenomena also open multiple research opportunities. We have proposed a research agenda that hopefully motivates further research and provides valuable insights to entrepreneurs and policy makers alike.

\section{About the Authors}

Ferran Giones is an Assistant Professor at the University of Southern Denmark in Sønderborg. He received his PhD from La Salle - Ramon Llull University in Barcelona, Spain. His research field is technology entrepreneurship, where he explores how and when technological progress transforms into entrepreneurial activity, and how this entrepreneurial activity results in sustainable organizations and innovative ecosystems.

Alexander Brem holds the Chair of Technology Management at Friedrich-Alexander-Universität Erlangen-Nürnberg (FAU) which is located at the Nuremberg Campus of Technology in Germany. Before joining FAU, Alexander was Professor of Technology and Innovation Management and Head of SDU Innovation and Design Engineering at the Mads Clausen Institute at the University of Southern Denmark in Sønderborg. His primary research interest is technology and innovation management with a special focus on interdisciplinary links to psychology, marketing, and entrepreneurship. 


\section{Digital Technology Entrepreneurship: A Definition and Research Agenda}

\section{Ferran Giones and Alexander Brem}

\section{References}

Amezcua, A. S., Grimes, M. G., Bradley, S. W., \& Wiklund, J. 2013. Organizational Sponsorship and Founding Environments: A Contingency View on the Survival of Business-Incubated Firms, 1994-2007. Academy of Management Journal, 56(6): 1628-1654. https://doi.org/10.5465/amj.2011.0652

Audretsch, D. B., Bönte, W., \& Mahagaonkar, P. 2012. Financial Signaling By Innovative Nascent Ventures: The Relevance of Patents and Prototypes. Research Policy, 41(8): 1407-1421. https://doi.org/10.1016/j.respol.2012.02.003

Bailetti, T. 2012. Technology Entrepreneurship: Overview, Definition, and Distinctive Aspects. Technology Innovation Management Review, 2(2): 5-12.

http://timreview.ca/article/520

Beckman, C. M., Eisenhardt, K., Kotha, S., Meyer, A., \& Rajagopalan, N. 2012. Technology Entrepreneurship. Strategic Entrepreneurship Journal, 6(2): 89-93. https://doi.org/10.1002/sej.1134

Bhawe, N., Rawhouser, H., \& Pollack, J. M. 2016. Horse and Cart: The Role of Resource Acquisition Order in New Ventures. Journal of Business Venturing Insights, 6: 7-13.

https://doi.org/10.1016/j.jbvi.2016.06.001

Brem, A., Nylund, P. A., \& Schuster, G. 2016. Innovation and De Facto Standardization: The Influence of Dominant Design on Innovative Performance, Radical Innovation, and Process Innovation. Technovation, 50-51: 79-88.

https://doi.org/10.1016/j.technovation.2015.11.002

Brem, A., \& Voigt, K.-I. 2009. Integration of Market Pull and Technology Push in the Corporate Front End and Innovation Management-Insights from the German Software Industry. Technovation, 29(5): 351-367. https://doi.org/10.1016/j.technovation.2008.06.003

Brown, R., \& Mason, C. 2014. Inside the High-tech Black Box: A Critique of Technology Entrepreneurship Policy. Technovation, 34(12): 773-784.

https://doi.org/10.1016/j.technovation.2014.07.013

Brush, C. G., Manolova, T. S., \& Edelman, L. F. 2008. Properties of Emerging Organizations: An Empirical Test. Journal of Business Venturing, 23(5): 547-566.

https://doi.org/10.1016/j.jbusvent.2007.09.002

Clarysse, B., Brunell, J., \& Wright, M. 2011. Explaining Growth Paths of Young Technology-Based Firms: Structuring Resource Portfolios in Different Competitive Environments. Strategic Entrepreneurship Journal, 157(5): 137-157. https://doi.org/10.1002/sej

Davidsson, P. 2015. Entrepreneurial Opportunities and the Entrepreneurship Nexus: A Re-conceptualization. Journal of Business Venturing, 30(5): 674-695.

https://doi.org/10.1016/j.jbusvent.2015.01.002

Dehlen, T., Zellweger, T., Kammerlander, N., \& Halter, F. 2014. The Role of Information Asymmetry in the Choice of Entrepreneurial Exit Routes. Journal of Business Venturing, 29(2): 193-209. https://doi.org/10.1016/j.jbusvent.2012.10.001

Doganova, L., \& Eyquem-Renault, M. 2009. What Do Business Models Do? Research Policy, 38(10): 1559-1570.

https://doi.org/10.1016/j.respol.2009.08.002
Drori, I., Honig, B., \& Sheaffer, Z. 2009. The Life Cycle of an Internet Firm: Scripts, Legitimacy, and Identity. Entrepreneurship Theory and Practice, 33(3): 715-738. https://doi.org/10.1111/j.1540-6520.2009.00323.x

Fauchart, E., \& Gruber, M. 2011. Darwinians, Communitarians, and Missionaries: The Role of Founder Identity in Entrepreneurship. Academy of Management Journal, 54(5): 935-957. https://doi.org/10.5465/amj.2009.0211

Ferreira, J. J. M., Ferreira, F. A. F., Fernandes, C. I. M. A. S., Jalali, M. S., Raposo, M. L., \& Marques, C. S. 2016. What Do We [Not] Know About Technology Entrepreneurship Research? International Entrepreneurship and Management Journal, 12(3): 713-733. https://doi.org/10.1007/s11365-015-0359-2

Frederiksen, D. L., \& Brem, A. 2017. How Do Entrepreneurs Think They Create Value? A Scientific Reflection Of Eric Ries' Lean Startup Approach. International Entrepreneurship and Management Journal, 13(1): 169-189.

https://doi.org/10.1007/s11365-016-0411-x

Fryges, H., \& Wright, M. 2014. The Origin of Spin-offs: A Typology of Corporate and Academic Spin-offs. Small Business Economics, 43(2): 245-259.

https://doi.org/10.1007/s11187-013-9535-3

Gans, J. S., \& Stern, S. 2003. The Product Market and the Market or "Ideas": Commercialization Strategies for Technology Entrepreneurs. Research Policy, 32(2): 333-350. https://doi.org/10.1016/S0048-7333(02)00103-8

Gedda, D., Nilsson, B., Såthén, Z., \& Solberg Søilen, K. 2016. Crowdfunding: Finding the Optimal Platform for Funders and Entrepreneurs. Technology Innovation Management Review, 6(3): 31-40.

https://timreview.ca/article/973

Gerlach, S., \& Brem, A. 2015. What Determines a Successful Business Incubator? Introduction to an Incubator Guide. International Journal of Entrepreneurial Venturing, 7(3): 286-307. https://doi.org/10.1504/IJEV.2015.071486

Giones, F., \& Miralles, F. 2015. Do Actions Matter More than Resources? A Signalling Theory Perspective on the Technology Entrepreneurship Process. Technology Innovation Management Review, 5(3): 39-45.

https://timreview.ca/article/880

Giones, F., \& Oo, P. 2017. How Crowdsourcing and Crowdfunding are Redefining Innovation Management. In A. Brem \& E. Viardot (Eds.), Revolution of Innovation Management: 43-70. London: Palgrave Macmillan UK. https://doi.org/10.1057/978-1-137-57475-6_3

Giones, F., Zhou, Z., Miralles, F., \& Katzy, B. 2013. From Ideas to Opportunities: Exploring the Construction of Technology-Based Entrepreneurial Opportunities. Technology Innovation Management Review, 3(6): 13-20.

http://timreview.ca/article/692

Gregory, R. W., \& Muntermann, J. 2014. Research Note-Heuristic Theorizing: Proactively Generating Design Theories. Information Systems Research, 25(3): 639-653.

https://doi.org/10.1287/isre.2014.0533

Gruber, M., MacMillan, I. C., \& Thompson, J. D. 2012. From Minds to Markets: How Human Capital Endowments Shape Market Opportunity Identification of Technology Start-Ups. Journal of Management, 38(5): 1421-1449.

https://doi.org/10.1177/0149206310386228 


\section{Digital Technology Entrepreneurship: A Definition and Research Agenda}

\section{Ferran Giones and Alexander Brem}

Gurses, K., \& Ozcan, P. 2015. Entrepreneurship in Regulated Markets: Framing Contests and Collective Action to Introduce Pay TV in the U.S. Academy of Management Journal, 58(6): 1709-1739. https://doi.org/10.5465/amj.2013.0775

Hanna, R., Rohm, A., \& Crittenden, V. L. 2011. We're All Connected: The Power of the Social Media Ecosystem. Business Horizons, 54(3): 265-273.

https://doi.org/10.1016/j.bushor.2011.01.007

Hartmann, D. 2014. Turning Technology into Business Using University Patents. Technology Innovation Management Review, 4(12): 37-43.

http://timreview.ca/article/856

Hesse, N., \& Sternberg, R. 2016. Alternative Growth Patterns Of University Spin-offs: Why So Many Remain Small? International Entrepreneurship and Management Journal, 1-32. http://dx.doi.org/10.1007/s11365-016-0431-6

Klyver, K., \& Schenkel, M. T. 2013. From Resource Access to Use: Exploring the Impact of Resource Combinations on Nascent Entrepreneurship. Journal of Small Business Management, 51(4): 539-556.

https://doi.org/10.1111/jsbm.12030

Kraus, S., Brem, A., Schuessler, M., Schuessler, F., \& Niemand, T. 2017. Innovative Born Globals: Investigating the Influence of Their Business Models on International Performance. International Journal of Innovation Management, 21(1): 1750005. https://doi.org/10.1142/S1363919617500050

Kyprianou, C. 2016. Getting to Network Effects: Social Club and Open Door Strategies in Two-sided Marketplaces. Academy of Management Proceedings. Anaheim, CA.

Lichtenstein, B. 2015. Emergence and Emergents in Entrepreneurship: Complexity Science Insights into New Venture Creation. Entrepreneurship Research Journal, 1-9. https://doi.org/10.1515/erj-2015-0052

MacInnis, D. J. 2011. A Framework for Conceptual Contributions in Marketing. Journal of Marketing, 75(4): 136-154. https://doi.org/10.1509/jmkg.75.4.136

Majchrzak, A., \& Malhotra, A. 2013. Towards an Information Systems Perspective and Research Agenda on Crowdsourcing for Innovation. The Journal of Strategic Information Systems, 22(4): 257-268.

https://doi.org/10.1016/j.jsis.2013.07.004

Mosey, S., Guerrero, M., \& Greenman, A. 2017. Technology Entrepreneurship Research Opportunities: Insights from Across Europe. The Journal of Technology Transfer, 42(1): 1-9. https://doi.org/10.1007/s10961-015-9462-3

Nambisan, S. 2016. Digital Entrepreneurship: Toward a Digital Technology Perspective of Entrepreneurship. Entrepreneurship Theory and Practice, (414): 1-27. https://doi.org/10.1111/etap.12254

Pauwels, C., Clarysse, B., Wright, M., \& Van Hove, J. 2016. Understanding a New Generation Incubation Model: The Accelerator. Technovation, 50-51: 13-24. https://doi.org/10.1016/j.technovation.2015.09.003
Priem, R. L., Li, S., \& Carr, J. C. 2011. Insights and New Directions from Demand-Side Approaches to Technology Innovation, Entrepreneurship, and Strategic Management Research. Journal of Management, 38(1): 346-374. https://doi.org/10.1177/0149206311429614

Rasmussen, E., \& Mathisen, M. T. 2016. Science-Based Entrepreneurial Firms as Real Options: Assessing the Outcomes of the Norwegian Firm Population From 1995 to 2012. In The World Scientific Reference on Entrepreneurship: Volume 4: Process Approach to Academic Entrepreneurship - Evidence from the Globe. London: World Scientific.

Rasmussen, E. S., \& Tanev, S. 2015. The Emergence of the Lean Global Startup as a New Type of Firm. Technology Innovation Management Review, 5(11): 12-19.

https://timreview.ca/article/941

Rusli, E. M., \& Eavis, P. 2012. Facebook Raises \$16 Billion in I.P.O. New York Times, May 17, 2012. Accessed May 1, 2017: https://dealbook.nytimes.com/2012/05/17/facebook-raises-16billion-in-i-p-o/

Shah, S. K., \& Tripsas, M. 2007. The Accidental Entrepreneur: The Emergent and Collective Process of User Entrepreneurship. Strategic Entrepreneurship Journal, 1(1): 123-140.

https://doi.org/10.1002/sej.15

Shepherd, D. A. 2010. Multilevel Entrepreneurship Research: Opportunities for Studying Entrepreneurial Decision Making. Journal of Management, 37(2): 412-420. https://doi.org/10.1177/0149206310369940

Srinivasan, R., Lilien, G., \& Rangaswamy, A. 2004. First In, First Out? The Effects of Network Externalities on Pioneer Survival. Journal of Marketing, 68(1): 41-58. http://dx.doi.org/10.1509/jmkg.68.1.41.24026

Tanev, S. 2012. Global from the Start: The Characteristics of BornGlobal Firms in the Technology Sector. Technology Innovation Management Review, 2(3): 5-8. http://timreview.ca/article/532

Tomczak, A., \& Brem, A. 2013. A Conceptualized Investment Model Of Crowdfunding. Venture Capital: An International Journal of Entrepreneurial Finance, 15(4): 335-359. https://doi.org/10.1080/13691066.2013.847614.

Wallin, A., Still, K., \& Henttonen, K. 2016. Entrepreneurial Growth Ambitions: The Case Of Finnish Technology Startups. Technology Innovation Management Review, 6(10): 5-16.

Wareham, J., Fox, P. B., \& Cano Giner, J. L. 2014. Technology Ecosystem Governance. Organization Science, 25(4): 1195-1215. https://doi.org/10.1287/orsc.2014.0895

Westerlund, M., Leminen, S., \& Rajahonka, M. 2014. Designing Business Models for the Internet of Things. Technology Innovation Management Review, 4(7): 5-14. http://timreview.ca/article/807

Wright, M., Hmieleski, K. M., Siegel, D. S., \& Ensley, M. D. 2007. The Role of Human Capital in Technological Entrepreneurship. Entrepreneurship Theory and Practice, 31(6): 791-806. https://doi.org/10.1111/j.1540-6520.2007.00202.x 